\title{
Heritable epigenetic mutation of MLHI in a mother and daughter with Lynch syndrome
}

\author{
Amie M Blanco ${ }^{1 *}$, Yunn-Yi Chen ${ }^{1}$, James P Grenert ${ }^{1}$, Stephen N Thibodeau², Jonathan P Terdiman ${ }^{1}$ \\ From 13th Annual Meeting of the Collaborative Group of the Americas on Inherited Colorectal Cancer \\ Honolulu, Hawaii, USA. 16-17 October 2009
}

\begin{abstract}
Background
Lynch syndrome is a hereditary predisposition to colorectal and endometrial cancers, in addition to cancers of the stomach, ovary, upper urinary tract, small bowel, hepatobiliary tract, skin and brain. Lynch syndrome is caused by defects in DNA mismatch repair (MMR), and germline mutations in MLHl, MSH2, MSH6 and PMS2 as well as high levels of tumor microsatellite instability (MSI) and loss of MMR protein expression are frequently found. MMR deficiency due to loss of MLH1 in tumor tissue may also be due to gene silencing resulting from hypermethylation of the MLH1 promoter, which is found in $15 \%$ of sporadic colorectal and endometrial cancers, and as the second "hit" in some individuals with germline mutations in MLH1. Recently, epigenetic silencing of MLH1 in normal body cells has been proposed as a novel cause of predisposition to Lynch syndrome associated tumors. Twenty five cases of hypermethylation of the MLH1 promoter in peripheral blood (MLH1 epimutation) of individuals with young onset colorectal cancer and/or endometrial cancer have been reported. The heritability of MLH1 epimutation is still under investigation.
\end{abstract}

\section{Methods and results}

A 39-year-old woman from the Philippines was diagnosed with stage III rectal cancer. Her rectal biopsy was screened for evidence of MMR deficiency, which showed high levels of MSI and loss of MLH1 and PMS2 protein expression. Her mother was diagnosed with synchronous colon and endometrial cancers at

\footnotetext{
* Correspondence: amie.blanco@ucsfmedctr.org

${ }^{1}$ University of California San Francisco, Helen Diller Family Comprehensive Cancer Center and Department of Medicine, San Francisco, California 94115, USA
}

age 40. She underwent germline mutation analysis of MLHl which failed to identify a mutation. Her rectal tumor was screened for MLH1 promoter methylation and BRAF V600E, which showed hypermethylation of the MLH1 promoter in both tumor and normal colonic mucosa, and negative BRAF V600E. Analysis of MLH1 promoter methylation in her peripheral blood was consistent with MLH1 epimutation. Tissue from her mother's colon tumor, endometrial tumor, and normal body tissue showed high levels of MSI, loss of MLH1 protein expression, negative BRAF V600E, and hypermethylation of the MLH1 promoter. Her mother died from her colon cancer in 1995, thus peripheral blood was not available. The patient has two unaffected siblings, ages 31 and 35, who have undergone MLH1 epimutation testing. Neither showed hypermethylation of the MLH1 promoter in peripheral blood.

\section{Conclusions}

This case report represents only the third known instance of maternal, transmission of MLH1 epimutation. The first was MLH1 epimutation in an unaffected son of a woman with endometrial, colorectal, and rectal cancers who was found to have MLH1 epimutation. The second was MLH1 epimutation in the 64-year-old unaffected mother of a young woman with colorectal cancer at age 39 and MLH1 epimutation. To our knowledge, our case is unique in that it represents the first case of MLH1 epimutation in a clinically affected mother and daughter, supporting the heritability of MLH1 epimutation as a rare but important cause of Lynch syndrome.

\footnotetext{
Author details

${ }^{1}$ University of California San Francisco, Helen Diller Family Comprehensive Cancer Center and Department of Medicine, San Francisco, California 94115,
} 
Published: 25 May 2010

doi:10.1186/1897-4287-8-S1-P3

Cite this article as: Blanco et al:: Heritable epigenetic mutation of MLHI

in a mother and daughter with Lynch syndrome. Hereditary Cancer in

Clinical Practice 2010 8(Suppl 1):P3.

Submit your next manuscript to BioMed Central and take full advantage of:

- Convenient online submission

- Thorough peer review

- No space constraints or color figure charges

- Immediate publication on acceptance

- Inclusion in PubMed, CAS, Scopus and Google Scholar

- Research which is freely available for redistribution

Submit your manuscript at www.biomedcentral.com/submit
() Biomed Central 